\title{
Ontogenesis of gonadotropin-releasing hormone neurons: a model for hypothalamic neuroendocrine cell development
}

\section{Erica L. Stevenson, Kristina M. Corella and Wilson C. J. Chung*}

Department of Biological Sciences, School of Biomedical Sciences, Kent State University, Kent, OH, USA

\author{
Edited by: \\ Pei-San Tsai, University of Colorado, \\ USA \\ Reviewed by: \\ Brian M. Shewchuk, East Carolina \\ University, USA \\ Sally Radovick, Johns Hopkins \\ University, USA \\ *Correspondence: \\ Wilson C. J. Chung, Department of \\ Biological Sciences, School of \\ Biomedical Sciences, Kent State \\ University, 222 Cunningham Hall, \\ Kent, OH 44242, USA \\ e-mail: wchung@kent.edu
}

The vertebrate hypothalamo-pituitary-gonadal axis is the anatomical framework responsible for reproductive competence and species propagation. Essential to the coordinated actions of this three-tiered biological system is the fact that the regulatory inputs ultimately converge on the gonadotropin-releasing hormone $(\mathrm{GnRH})$ neuronal system, which in rodents primarily resides in the preoptic/hypothalamic region. In this short review we will focus on: (1) the general embryonic temporal and spatial development of the rodent $\mathrm{GnRH}$ neuronal system, (2) the origin(s) of GnRH neurons, and (3) which transcription - and growth factors have been found to be critical for $\mathrm{GnRH}$ neuronal ontogenesis and cellular fate-specification. Moreover, we ask the question whether the molecular and cellular mechanisms involved in $\mathrm{GnRH}$ neuronal development may also play a role in the development of other hypophyseal secreting neuroendocrine cells in the hypothalamus.

Keywords: GnRH, hypothalamus, fibroblast growth factor 8, embryonic and fetal development, neuroendocrine cells

\section{INTRODUCTION}

The ability of an organism to reproduce is of critical importance to the survival of not only the individual, but also of the species at large. In mammals, reproduction is under the tight regulation of a three-tiered body axis that consists of the neurons found in the preoptic area and hypothalamus, pituitary cells, and gonadal tissues, and therefore has been called the hypothalamo-pituitary-gonadal (HPG) axis. Functionally, gonadotropin-releasing hormone $(\mathrm{GnRH})$ neurons are viewed as the most upstream regulatory component of the HPG axis. Most $\mathrm{GnRH}$ neurons are found around the very anterior tip of the third ventricle called the organum vasculosum lamina terminalis (OVLT) and their axons project to the external zone of the median eminence (ME) in order to release the decapeptide, GnRH, into the portal vein system. This in turn stimulates gonadotropin production and release from the gonadotrophs of the anterior pituitary into systemic circulation, ultimately causing steroidogenesis and gametogenesis in the gonads.

Key publications in the late 80s described in detail the neuroanatomical embryonic development of $\mathrm{GnRH}$ neurons in the rodent $(1,2)$. Based on the results of these landmark studies, a compelling argument has been made favoring that GnRH neurons originate (i.e., born) in the nasal compartment, at the level of the olfactory placode (OP), and migrate along the nasal septum to the preoptic region and hypothalamus by following the olfactory, vomeronasal, and terminal nerves $(1,3)$. Currently, the best estimates based on measurable GnRH peptide and mRNA levels suggest that this developmental process begins around embryonic day (E) 9.5, and is completed around E16.5 $(1,3)$.

Numerous studies have shown that the number of GnRH neurons in the mammalian brain is very limited. Indeed, the adult mouse and rat brain has a total of about $800-1000 \mathrm{GnRH}$ neurons
(4-7). Interestingly, there are studies reporting that those adult GnRH neurons are what remain from a larger pool of approximately 1900-2000 embryonic GnRH neurons found around E12.75 (7). These studies suggest that in addition to GnRH neuron path-finding, there is also an inherent selection process that takes place while GnRH neurons are migrating, which pares down the number of GnRH neurons in the adult rodent brain to $800-1000$ total.

In this review, we will primarily focus on the central portion of the HPG axis; specifically, we will discuss in detail the mechanisms involved in GnRH neuronal ontogenesis and fatespecification. Moreover, we will discuss how this knowledge may be useful for understanding the embryonic development of other neuroendocrine cell types that have been found in the preoptic region and the hypothalamus.

\section{PRESUMPTIVE ORIGINS GnRH NEURONS OLFACTORY PLACODE}

As previously alluded to, GnRH neurons are first found outside the central nervous system (CNS), even though the CNS is their final residence. Using immunocytochemistry and in situ hybridization, two landmark studies showed that GnRH expressing cells could be found only in a specific part of the nasal compartment, the OP, on E11.5 from which they migrate to the forebrain $(1,3)$.

Interestingly, proliferation studies showed that the vast majority ( $\sim 80 \%)$ of mouse GnRH neurons undergo their last division in the medial-ventral OP between E9.5 and E10.5 (2). These data suggest that the anatomical localization of $\mathrm{GnRH}$ progenitor cell ontogenesis is localized in the embryonic medial-ventral OP. Interestingly, these post-mitotic GnRH progenitor cells do not express detectable levels of GnRH mRNA or peptide prior to E11.5 (1, 2). In this sense, one can define the period of GnRH neuronal 
fate-specification to occur between E9.5 and E11.5. The absence of measurable GnRH peptide prior to E11.5 is a major hurdle for studying the molecular processes that regulate $\mathrm{GnRH}$ neuronal fate-specification because, at present, the only marker for GnRH neurons is the ability to express the GnRH peptide itself. Therefore, post-mitotic OP progenitor cells that are destined to become GnRH neurons cannot be identified during a large portion of fate-specification, before they express measurable $\mathrm{GnRH}$ peptide levels. Taken together, these studies make a strong case supporting the central hypothesis that $\mathrm{GnRH}$ progenitor cells are born, and become post-mitotic in the medial-ventral OP.

Further support for this hypothesis comes from the observation that humans who are deficient in GnRH signaling not only exhibit hypogonadotropic hypogonadism, which causes infertility, but are also completely or partially lacking the ability to smell (i.e., anosmia or hyposmia) (8-11). One such reproductive disorder in humans is known as Kallmann syndrome (KS) (12-16). The presence of olfactory function defects in KS patients is in line with the observation that the presumably "newly" born GnRH progenitor cells are first detected in the medial-ventral OP.

The OP is an ectodermal region that gives rise to both nonsensory respiratory epithelium and sensory olfactory epithelium. The olfactory epithelium eventually develops into the main olfactory and vomeronasal systems $(17,18)$. Ablation studies have provided supporting evidence for the OP being the birthplace of GnRH neurons, albeit sometimes ambiguously. For example, amphibians that undergo OP removal ultimately lack the olfactory epithelium, nerve, and bulb, as well as, GnRH neurons of the forebrain $(19,20)$. Interestingly, when the OP is removed in rat and chick embryos it does not result in total loss of forebrain $\mathrm{GnRH}$ neurons. Rather, small populations of $\mathrm{GnRH}$ neurons are found in the septum of rats, suggesting that these did not arise from the OP $(21,22)$. However, it has been argued that the method of ablation may have allowed some of the OP cells to survive, consequently allowing the emergence of a limited population of $\mathrm{GnRH}$ neurons to migrate to the septum.

Studies in chicks further pinpointed that forebrain $\mathrm{GnRH}$ neurons are eliminated only when the respiratory epithelium is ablated, and not the olfactory epithelium (23). Conversely, ablation of the olfactory epithelium does not affect the development of the GnRH neuronal system in chicks $(24,25)$. Nonetheless, only a small percentage of GnRH neurons have been found migrating from the respiratory epithelium of normal chicks, whilst the majority of GnRH neurons are from the olfactory epithelium (26). Studies in mice have shown that GnRH neurons are not exclusively localized in the olfactory epithelium, but can also be found in the respiratory epithelium (27) as delineated using the transcription factor marker activator protein $2 \alpha(\mathrm{AP} 2 \alpha)$. Moreover, $\mathrm{AP} 2 \alpha$ is reported to be co-localized in some of these newly formed $\mathrm{GnRH}$ neurons (27). In the same study, a number of GnRH neurons were found to be positive for nestin, which is another marker of the respiratory epithelium. In contrast, some $\mathrm{GnRH}$ neurons do not express olfactory epithelium markers, such as Mash-1, Math4A, Math4C/neurogenin1, and NeuroD (27). Taken together, these data demonstrate that both the respiratory and olfactory epithelium may contribute significantly to the OP's ability to generate $\mathrm{GnRH}$ neurons. This conclusion, along with the inability to directly follow
GnRH progenitor cells from their birth (due to lack of a marker for GnRH neurons other than the GnRH peptide itself) has led to a proposed alternative birth place of GnRH neurons other than the olfactory epithelium in the OP (see below).

\section{NEURAL CREST}

Studies of the GnRH neuronal system in zebrafish have cast increasing doubt on the accepted paradigm that $\mathrm{GnRH}$ neurons originate solely from within the olfactory epithelium in the medial-ventral OP. For example, analysis of two knockout zebrafish strains, you-too and detour, showed that not only is the pituitary lacking or reduced, but there is also a concomitant loss of hypothalamic GnRH neurons $(28,29)$. Interestingly, these animals have normal olfactory organ development suggesting that the loss of GnRH neurons cannot be due to the loss of the OP. This inconsistency in GnRH neuronal origin may be due to species differences. Indeed, mouse homologs of the aforementioned zebrafish pituitary knockouts do not show a loss of GnRH neurons (30-33). Therefore, we can infer that GnRH progenitor cells are not likely to originate from the developmental tissues that give rise to the anterior pituitary in mammals.

In several vertebrate species the neural crest has been implicated as a possible contributor to the formation of the OP (34-36). This region arises from the edge of the neural plate and shares a border with the region that eventually becomes the OP. Neural crest cells have been shown to migrate toward the presumptive OP, and therefore, are likely to have contributed specific cell populations to the developing OP (37). Conclusive evidence supporting this inference comes from zebrafish studies where premigratory neural crest cells were labeled with lysinated rhodamine dextran in vivo $(38,39)$. Subsequent double-labeling studies showed that a subset of the tagged neural crest cells expressed GnRH mRNA and peptide during the migratory phase of GnRH neuronal development (29).

These original data have been recently replicated in mice. Indeed, a small proportion (i.e., 30\%) of the GnRH neurons found in the OP had a genetic lineage similar to cells that arise in the neural crest $(35,40)$. However, the other $70 \%$ of the total population of $\mathrm{GnRH}$ neurons originated from placodal ectoderm progenitors. In contrast, recent cell fate tracing studies in chicks determined that all $\mathrm{GnRH}$ progenitors originate from ectodermal placodes, suggesting that the developing neural crest does not contribute to the emergence of $\mathrm{GnRH}$ progenitors in this species (41). In short, GnRH neurons are likely to originate from both the neural crest and OP. However, the degree to which each of these two proliferative zones contributes to the GnRH neuronal system may be species-dependent.

\section{GENES REGULATING NEUROENDOCRINE CELL DEVELOPMENT}

The anatomical development of hypothalamic neuroendocrine cells has been studied in much detail since the late 70s. For instance, Altman and Bayer showed that hypothalamic cells are primarily born during the second half of rat gestation, and originate from the neuroepithelium of the fetal third ventricle (42). Since then, many studies have contributed to the elucidation of the underlying molecular mechanisms of hypothalamic morphogenesis. 
Unlike other hypothalamic neuroendocrine cells, the origins of GnRH neurons are extra-hypothalamic; however, the development of the GnRH neuronal system is arguably one of the best-studied neuroendocrine cell systems within the hypothalamus. Consequently, it is possible that some of the molecular factors that have been found to regulate GnRH neuronal development in the nasal and forebrain compartments may also be relevant, and involved in the embryonic development of non-GnRH hypothalamic neuroendocrine cells, such as those that express vasopressin and oxytocin.

Due to major advances in molecular techniques over the last couple of decades it has become possible to genetically screen individuals with GnRH deficiencies. For example, KS patients have been extensively screened in order to study whether they harbor specific gene mutation(s) that may have led to their infertility and olfactory deficits. These studies have identified many factors regulating fate-specification and migration of $\mathrm{GnRH}$ neurons [as reviewed in (43-47)]. Some of these factors and their contributions are described below.

The first mutated gene to be found in KS patients was anosmin1 (as described below) (48-50). Following genetic screening, studies found further evidence supporting the idea that KS may be the result of a myriad of mutated genes. Indeed, KS patients have been shown to harbor hemizygous mutations for fibroblast growth factor receptor-1 $(F g f r 1)(13,51,52)$, fibroblast growth factor 8 ( Fgf8) $(14,15,53)$, prokineticin 2 (Prok2) (54) and its receptor (Prokr2) (55), and chromodomain helicase-DNA-binding 7 (Chd7) (5658). These studies have been instrumental in providing possible candidate genes that may play a role in $\mathrm{GnRH}$ progenitor cell fatespecification, and possibly provide further insight into the origin of GnRH neurons.

\section{ANOSMIN-1}

Studies in humans revealed that $K A L-1$ mutations underlie the X-linked form of KS in humans (13, 48, 49, 59, 60). KAL-1 (also known as Anosmin-1) encodes an extracellular matrix protein that is secreted by the cranial neural crest, a developmental region in mice from which approximately $30 \%$ of the GnRH progenitors originate, and provides autocrine regulation of neural crest formation in chicks (61). Anosmin-1 plays a role in the regulation of $\mathrm{GnRH}$ neuronal migration in rats and humans by promoting the formation of the lateral olfactory tract and the collateral branches of the mitral and tufted cells toward the olfactory cortex (13, 62-65). It does this, in part, by promoting FGF signaling (66).

There is evidence that anosmin-1 expressing cells are readily found within the hypothalamus in rats and zebrafish (67, 68). Interestingly, recent studies have identified the presence of anosmin-1 protein within bipolar cells in the most rostral hypothalamic neuroepithelium that lines the third ventricle in rat embryos (67), which has been shown to be the proliferative zone that gives rise to many, if not all, hypothalamic neurons (42). Furthermore, it has been reported that these hypothalamic neuroepithelia anosmin-1 positive cells are not detected in the same region in postnatal rats. Currently, the identity and the function of these anosmin-1 positive cells are unknown. Based on its function during GnRH neuron migration, it may be speculated that these anosmin-1 cells facilitate radial or tangential neuroendocrine cell migration from the proliferative zone of the third ventricle.

\section{FIBROBLAST GROWTH FACTOR RECEPTOR-1 AND FIBROBLAST GROWTH FACTOR 8}

Studies in humans and rodents have cemented the concept that FGF signaling is critically important for GnRH progenitor cell birth and proliferation $(15,16,69,70)$. Moreover, loss-of-function mutations in both Fgfrl and $F g f 8$ have been detected in KS patients $(15,51)$. Our basic studies using homozygous Fgfrl and Fgf8 hypomorphic newborn mice showed that the GnRH neuronal system was reduced (i.e., $\sim 90 \%$ ) or completely absent, respectively (14, $15)$. Moreover, the GnRH neuronal population in the heterozygous $F g f r 1$ and $F g f 8$ hypomorphs was also significantly reduced as compared to the wildtype newborns $(14,15)$. Following studies furthermore found evidence that the reduced GnRH neuronal system in these hypomorphic mice causes abnormal reproductive function (71). Together, these results provided a fundamental explanation for the reproductive defects found in KS patients who harbor Fgfrl and/or Fgf8 mutations.

The elimination of GnRH neurons likely occurred during the emergence phase of GnRH neuronal development (i.e., E9.5E11.5). In contrast to wildtype E11.5 embryos, no GnRH neurons were detected in the medial-ventral OP of homozygous Fgf8 hypomorphs (14). Currently, it is unknown whether the elimination of the GnRH progenitor cells is the cause of abrogated FGF8-dependent proliferation or cell survival. However, circumstantial evidence favors the second option given that the presence of increased apoptosis has been reported for the E10.5 OP (70).

Subsequent studies in non-GnRH neuroendocrine systems in the mouse hypothalamus showed that FGF signaling is also involved in the development of hypothalamic neuroendocrine cells that express kisspeptin, vasopressin, and oxytocin (70-73). Specifically, the number of kisspeptin neurons in the adult heterozygous hypomorphic Fgfrl and Fgfs compound mice was significantly higher than wildtype mice (71). Currently, it is unknown whether the increase in kisspeptin neurons in these compound Fgfrl/Fgf8 mice is the result of increased proliferation or survival of kisspeptin neurons during embryonic development. Alternatively, a more parsimonious explanation could be that the kisspeptin system has been "ramped" up as a compensatory mechanism to counter the reduction in the number of GnRH neurons in these compound Fgfrl/Fgf8 hypomorphic mice.

It should be noted that FGF signaling may play a role in maintaining neurochemical phenotype/identity. Indeed, Brooks and colleagues recently reported a major reduction in the number of oxytocin neurons in the paraventricular nucleus (PVN) and supraoptic nucleus (SON) of the hypothalamus (72). Upon further examination, an interesting divergent role of FGF8 signaling during oxytocin neuronal development was detected. Indeed, while the loss of oxytocin neurons in the SON was correlated with a loss in the oxyphysin-prohormone levels, this was not the case for the PVN oxytocin neurons (72). These data indicate that FGF8 signaling plays a role in shaping the hypothalamic oxytocin system on two levels: anatomy (i.e., cell number) and cellular neuropeptide processing. 
The hypothalamic vasopressinergic system was also highly compromised in heterozygous and homozygous Fgf8 hypomorphic newborn mice (73). Specifically, the number of vasopressin neurons was found to be reduced in the PVN, SON, and suprachiasmatic nucleus (SCN) (73). Interestingly, the percentage of vasopressin neuronal loss was much higher in the SCN than in the PVN suggesting a ventral-dorsal gradient in FGF8-dependence. These results are in line with previous studies showing that $F g f 8$ mRNA expression in the E13.5 mouse embryo is highest in the ventral zone of the developing hypothalamus, which diminishes dorsally (Allen Developing Mouse Brain Atlas). Taken together, these studies support the proposition that the ventral hypothalamic neuroendocrine cells (i.e., vasopressin or oxytocin) are more dependent, and hence, vulnerable to disruptions in FGF8 signaling during embryonic development.

\section{PROKINETICIN 2/PROKINETICIN RECEPTOR 2}

In contrast to the FGF signaling system, Prok2 (74) and its Gprotein coupled receptor (Prokr2) (75-77) were shown to primarily regulate GnRH neuron migration and neuroendocrine function in Prok2 and Prokr2 null mutant mouse studies (78-80), which may underlie the abnormal or absent pubertal onset found in humans $(54,80)$.

Prokineticin 2 null animals display a greatly reduced number of GnRH neurons in the medial preoptic area, and $50 \%$ of them show asymmetric olfactory bulb neurogenesis $(78,80)$. The loss of medial preoptic GnRH neurons is likely due to the malformation of the olfactory vomeronasal axonal pathways (79). Humans with mutations in Prok2 or Prokr2 present with either KS or normosmic hypogonadotropic hypogonadism $(54,55,81)$. Interestingly, Prok2 and Prokr2 are not localized in GnRH neurons (80). Due to this fact, it has been suggested that Prok2/Prokr2 impact GnRH migration by acting on the fibers that guide $\mathrm{GnRH}$ neurons into the forebrain (82).

Both Prok2 and Prokr2 expression has been localized within several nuclei of the hypothalamus, most notably in the mouse SCN and PVN (83). Indeed, Prokr2 null mice have disruptions in circadian activity and thermoregulation, which are two major functions of the hypothalamus (84). Thus far, it is unknown whether the loss of Prokr2 expression causes developmental defects within the embryonic organization of the SCN. However, it is known that Prokr2 null mice exhibit defective neuronal progenitor proliferation and migration from the subventricular zone, which is likely to underlie the decreased volume of the olfactory bulbs (85). This defect was further compounded by the increased levels of olfactory bulb apoptosis (85). Taken together, these data favor the possibility that Prok2 and Prokr2 may also be involved in the embryonic organization of hypothalamic neuroendocrine cells.

\section{CHROMODOMAIN HELICASE-DNA-BINDING 7}

Chromodomain helicase-DNA-binding 7 mutations have been causally linked to the main cause of CHARGE syndrome, a disorder that is characterized by a number of symptoms, including heart defects, ocular coloboma, genital hypoplasia, and KS (86). Mouse studies have shown that Chd7 expression is present in the OP from E10.5 onward, which could explain why CHARGE syndrome patients manifest anosmia and hypogonadotropin hypogonadism
(56). In line with these clinical observations, Chd7 null mice have compromised reproductive fitness and significantly less $\mathrm{GnRH}$ neurons (87). The reduction of GnRH neurons may be linked to the lower levels of cellular proliferation in the E10.5 OP (87). Currently, there are no studies implicating that Chd7 might also play a role in the development of non-GnRH hypothalamic neuroendocrine cells.

\section{PAX}

The PAX family of transcription factors contains a unique DNA binding sequence known as the paired-box, a DNA binding homeo-domain $(88,89)$. To date, there have been 9 Pax genes isolated and all but PAX-1 have been localized in the developing CNS (89). This family has been described to be involved in early animal development and tissue specification.

Pax-6 is of special interest because of its importance during the development of the eye, olfactory system, and forebrain. Mice with a semi-dominant point mutation in the Pax-6 gene are known as small-eye (Sey) $(90,91)$. Sey homozygotes do not develop eyes or an OP, and do not survive to birth $(92,93)$. In mice, Pax-6 expression can be detected in mice on E8.5 in the eye, olfactory system, pituitary, brain, and spinal cord (94-96). Furthermore, PAX-6 is localized in the neocortex, lateral ganglionic eminence, thalamus, and hypothalamus (97).

Sey heterozygotes survive to postpartum, but suffer varying degrees of eye malformations $(92,98,99)$. Since Sey mice do not form OPs they have been useful models for examining the origins of GnRH neurons. Indeed, Sey homozygotes completely lack GnRH neurons in all regions of the brain (100), which provides further evidence supporting the medial-ventral OP as the birth place of GnRH progenitor cells. Of course, the absence of OP development may also have been detrimental to $\mathrm{GnRH}$ progenitor cells that are of neural crest origin (35).

No direct evidence has been reported about the role of PAX-6 during the hypothalamic neuroendocrine development. However, mapping studies have shown that Pax-6 expression can be found in the subventricular neuroepithelium cells of the third ventricle in the E14.5 mouse hypothalamus $(97,101)$. Furthermore, anatomical studies in Sey mice have reported that the compartmentalization of the embryonic hypothalamus is disrupted causing it to expand beyond its normal boundaries (101). Furthermore, tracing studies have shown that the mammillothalamic tract is abnormal in Sey null mouse hypothalamus (102). Therefore, it is possible that Pax-6 may be important for the emergence of non-GnRH hypothalamic neuroendocrine cells, although this has not yet been studied in great detail.

\section{sox}

The Sox gene family belongs to the high mobility group (HMG) superfamily (103). These proteins bind to the minor groove of DNA in a highly sequence-specific manner (104-106). There have been at least 20 Sox genes identified, which are categorized into eight classes (A-H). Although the Class B Sox genes are known to be involved in embryonic neuronal development (107) and differentiation of the neuroepithelium (108), it is the Class C Sox genes that provide evidence of a role in the regulation of GnRH expression. There are two SOX-binding sites located on the 
intron A region of $G n R H$, which possesses a putative transcriptional enhancer. When tested, only SOX-4 and SOX-11 (members of Class C) dramatically increased luciferase reporter activity (109). Both SOX-4 and SOX-11 were localized within $\sim 80 \%$ of $\mathrm{GnRH}$ neurons and found in significantly lower abundance in non-GnRH hypothalamic cells (109). To our knowledge, there are no data available describing the role of SOX-4 or SOX-11 during hypothalamic neuroendocrine cell development.

\section{CONCLUSION}

In this short, and by no means exhaustive review we argue that the molecular mechanisms involved during GnRH neuronal fetal development may also provide some insights into the development of non-GnRH hypothalamic neuroendocrine cells. In general this approach has been fruitful in elucidating some aspects

\section{REFERENCES}

1. Schwanzel-Fukuda M, Pfaff DW. Origin of luteinizing hormonereleasing hormone neurons. Nature (1989) 338:161-4. doi:10.1038/338161a0

2. Wray S, Grant $\mathrm{P}$, Gainer $\mathrm{H}$. Evidence that cells expressing luteinizing hormone-releasing hormone mRNA in the mouse are derived from progenitor cells in the olfactory placode. Proc Natl Acad Sci $\begin{array}{llll}U & S & A & \text { (1989) 86:8132-6. }\end{array}$ doi:10.1073/pnas.86.20.8132

3. Wray S, Nieburgs A, Elkabes S. Spatiotemporal cell expression of luteinizing hormone-releasing hormone in the prenatal mouse: evidence for an embryonic origin in the olfactory placode. Brain Res Dev Brain Res (1989) 46:309-18. doi:10.1016/01653806(89)90295-2

4. Shivers BD, Harlan RE, Morrell JI, Pfaff DW. Immunocytochemical localization of luteinizing hormone-releasing hormone in male and female rat brains. Quantitative studies on the effect of gonadal steroids. Neuroendocrinology (1983) 36:1-12. doi:10.1159/000123522

5. King JC, Anthony EL. LHRH neurons and their projections in humans and other mammals: species comparisons. Peptides (1984) 5(Suppl 1):195-207. doi:10.1016/01969781(84)90277-8

6. Wray S, Hoffman G. A developmental study of the quantitative distribution of LHRH neurons within the central nervous system of postnatal male and female rats. $J$ Comp Neurol (1986) 252:522-31. doi:10.1002/cne.902520408

7. Wu TJ, Gibson MJ, Rogers MC, Silverman AJ. New observations on the development of the gonadotropin-releasing hormone system in the mouse. J Neurobiol (1997) 33:983-98. doi:10.1002/(SICI) 1097 4695(199712)33:7<983::AIDNEU9>3.0.CO;2-4

8. Cariboni A, Maggi R. Kallmann's syndrome, a neuronal migration defect. Cell $\mathrm{Mol}$ Life Sci (2006) 63:2512-26. doi:10.1007/s00018-005-5604-3

9. Chan YM, Broder-Fingert $S$, Seminara SB. Reproductive functions of kisspeptin and Gpr54 across the life cycle of mice and men. Peptides (2009) 30:42-8. doi:10.1016/ j.peptides.2008.06.015

10. Trarbach EB, Teles MG, Costa EM, Abreu AP, Garmes HM, Guerra G Jr., et al. Screening of autosomal gene deletions in patients with hypogonadotropic hypogonadism using multiplex ligation-dependent probe amplification: detection of a hemizygosis for the fibroblast growth factor receptor 1 . Clin Endocrinol (Oxf) (2010) 72:371-6. doi:10.1111/j.13652265.2009.03642.x

11. Wray S. From nose to brain: development of gonadotrophinreleasing hormone-1 neurones. J Neuroendocrinol (2010) 22:743-53. doi:10.1111/j.13652826.2010.02034.x

12. Kallmann F. The genetic aspects of primary eunuchoidism. Am J Ment Defic (1944) 48:203-36.

13. Schwanzel-Fukuda M, Bick D, Pfaff DW. Luteinizing hormone-releasing hormone (LHRH)-expressing cells do not migrate normally in an inherited hypogonadal (Kallmann) syndrome. Brain Res Mol Brain Res (1989)

of the molecular underpinning of neuroendocrine cells during their fetal development. As such, a promising and well-described candidate seems to be FGF8. Indeed, mice that are hypomorphic for $F g f 8$ exhibit dramatic GnRH and non-GnRH hypothalamic neuroendocrine cell defects (see above). However, there are still many questions that arise from these observations. For instance, do these factors affect the proliferation, fate-specification, migration, and/or survival of hypothalamic neuroepithelium that are destined to become part of the various neuroendocrine systems in the hypothalamus? Moreover, do other members of the reviewed signaling systems also play a role in the development of the hypothalamus? The direct examination of these types of questions will be beneficial in order to better understand the fetal organization of the hypothalamic neuroendocrine systems.

6:311-26. doi:10.1016/0169328X(89)90076-4

14. Chung WCJ, Moyle SS, Tsai PS. Fibroblast growth factor 8 signaling through fibroblast growth factor receptor 1 is required for the emergence of gonadotropin-releasing hormone neurons. Endocrinology (2008) 149:4997-5003. doi:10.1210/en.2007-1634

15. Falardeau J, Chung WCJ, Beenken A, Raivio T, Plummer L, Sidis Y, et al. Decreased FGF8 signaling causes deficiency of gonadotropin-releasing hormone in humans and mice. $J$ Clin Invest (2008) 118:2822-31. doi:10.1172/JCI34538

16. Chung WCJ, Tsai PS. Role of fibroblast growth factor signaling in gonadotropinreleasing hormone neuronal system development. Front Horm Res (2010) 39:37-50. doi:10.1159/000312692

17. Halpern M. The organization and function of the vomeronasal system. Annu Rev Neurosci (1987) 10:325-62. doi:10.1146/ annurev.ne.10.030187.001545

18. Farbman AI, Buchholz JA Growth of olfactory epithelial tissue in vitro: lectin staining of axons. Microsc Res Tech (1992) 23:173-80. doi:10.1002/jemt.1070230207

19. Murakami S, Kikuyama S, Arai Y. The origin of the luteinizing hormone-releasing hormone (LHRH) neurons in newts (Cynops pyrrhogaster): the effect of olfactory placode ablation. Cell Tissue Res (1992) 269:21-7. doi:10.1007/BF00384722

20. Northcutt RG, Muske LE. Multiple embryonic origins of gonadotropin-releasing hormone (GnRH) immunoreactive neurons. Brain Res
Dev Brain Res (1994) 78:279-90. doi:10.1016/01653806(94)90037-X

21. Daikoku-Ishido H, Okamura $Y$, Yanaihara N, Daikoku S. Development of the hypothalamic luteinizing hormone-releasing hormone-containing neuron system in the rat: in vivo and in transplantation studies. Dev Biol (1990) 140:374-87. doi:10.1016/00121606(90)90087-Y

22. Daikoku S, Koide I. Spatiotemporal appearance of developing LHRH neurons in the rat brain. $J$ Comp Neurol (1998) 393:34-47. doi:10.1002/(SICI)10969861(19980330)393:1<34::AIDCNE4>3.0.CO;2-R

23. el Amraoui A, Dubois PM. Experimental evidence for an early commitment of gonadotropin-releasing hormone neurons, with special regard to their origin from the ectoderm of nasal cavity presumptive territory. Neuroendocrinology (1993) 57:991-1002. doi:10.1159/000126490

24. Akutsu S, Takada M, OhkiHamazaki H, Murakami S, Arai Y. Origin of luteinizing hormonereleasing hormone (LHRH) neurons in the chick embryo: effect of the olfactory placode ablation. Neurosci Lett (1992) 142:241-4. doi:10.1016/03043940(92)90382-H

25. Arai Y, Murakami S, Seki T. Removal of olfactory placode prevents the development of LHRH neurons in the forebrain of the chick embryo: possible interaction between migrating LHRH neurons and highly polysialylated form of neural cell adhesion molecule (NCAMH). Acta Biol Hung (1994) 45:155-68. 
26. Hilal EM, Chen JH, Silverman AJ. Joint migration of gonadotropin-releasing hormone $(\mathrm{GnRH})$ and neuropeptide $\mathrm{Y}$ (NPY) neurons from olfactory placode to central nervous system. $J$ Neurobiol (1996) 31:487-502. doi:10.1002/(SICI) 10974695(199612)31:4<487::AIDNEU8 $>3.0 . \mathrm{CO} ; 2-5$

27. Kramer PR, Wray S. Midline nasal tissue influences nestin expression in nasalplacode-derived luteinizing hormone-releasing hormone neurons during development. Dev Biol (2000) 227:343-57. doi:10.1006/dbio.2000.9896

28. Karlstrom RO, Talbot WS, Schier AF. Comparative synteny cloning of zebrafish you-too: mutations in the Hedgehog target gli2 affect ventral forebrain patterning. Genes Dev (1999) 13:388-93. doi:10.1101/gad.13.4.388

29. Whitlock KE, Wolf CD, Boyce ML. Gonadotropin-releasing hormone $(\mathrm{GnRH})$ cells arise from cranial neural crest and adenohypophyseal regions of the neural plate in the zebrafish, Danio rerio. Dev Biol (2003) 257:140-52. doi:10.1016/S00121606(03)00039-3

30. Sheng HZ, Zhadanov $A B$, Mosinger B Jr., Fujii T, Bertuzzi S, Grinberg A, et al. Specification of pituitary cell lineages by the LIM homeobox gene Lhx3. Science (1996) 272:1004-7. doi:10.1126/science.272.5264.1004

31. Mo R, Freer AM, Zinyk DL, Crackower MA, Michaud J, Heng $\mathrm{HH}$, et al. Specific and redundant functions of Gli2 and Gli3 zinc finger genes in skeletal patterning and development. Development (1997) 124:113-23.

32. Park HL, Bai C, Platt KA, Matise MP, Beeghly A, Hui CC, et al. Mouse Glil mutants are viable but have defects in SHH signaling in combination with a Gli2 mutation. Development (2000) 127:1593-605.

33. Metz H, Wray S. Use of mutant mouse lines to investigate origin of gonadotropin-releasing hormone-1 neurons: lineage independent of the adenohypophysis. Endocrinology (2010) 151:766-73. doi:10.1210/en.2009-0875

34. Whitlock KE, Westerfield M. The olfactory placodes of the zebrafish form by convergence of cellular fields at the edge of the neural plate. Development (2000) 127:3645-53.

35. Forni PE, Taylor-Burds C, Melvin VS, Williams T, Wray S. Neural crest and ectodermal cells intermix in the nasal placode to give rise to GnRH-1 neurons, sensory neurons, and olfactory ensheathing cells. $J$ Neurosci (2011) 31:6915-27. doi:10.1523/ JNEUROSCI.6087-10.2011

36. Katoh H, Shibata S, Fukuda K, Sato M, Satoh E, Nagoshi N, et al. The dual origin of the peripheral olfactory system: placode and neural crest. Mol Brain (2011) 4:34. doi:10.1186/17566606-4-34

37. Schilling TF, Kimmel CB. Segment and cell type lineage restrictions during pharyngeal arch development in the zebrafish embryo. Development (1994) 120:483-94.

38. Raible DW, Wood A, Hodsdon W, Henion PD, Weston JA, Eisen JS. Segregation and early dispersal of neural crest cells in the embryonic zebrafish. Dev Dyn (1992) 195:29-42. doi:10.1002/aja.1001950104

39. Raible DW, Eisen JS. Restriction of neural crest cell fate in the trunk of the embryonic zebrafish. Development (1994) 120:495-503.

40. Forni PE, Wray S. Neural crest and olfactory system: new prospective. $\mathrm{Mol} \mathrm{Neu-}$ robiol (2012) 46:349-60. doi:10.1007/s12035-012-8286-5

41. Sabado V, Barraud P, Baker CV, Streit A. Specification of GnRH-1 neurons by antagonistic FGF and retinoic acid signaling. Dev Biol (2012) 362:254-62. doi:10.1016/j.ydbio.2011.12.016

42. Altman J, Bayer SA. Development of the diencephalon in the rat. VI. Re-evaluation of the embryonic development of the thalamus on the basis of thymidine-radiographic datings. J Comp Neurol (1979) 188:50124. doi:10.1002/cne. 901880310

43. Tobet SA, Bless EP, Schwarting GA. Developmental aspect of the gonadotropinreleasing hormone system. Mol Cell Endocrinol (2001) 185:173-84. doi:10.1016/S03037207(01)00616-5

44. Wierman ME, Pawlowski JE, Allen MP, Xu M, Linseman DA, Nielsen-Preiss S. Molecular mechanisms of gonadotropinreleasing hormone neuronal migration. Trends Endocrinol
Metab (2004) 15:96-102. doi:10.1016/j.tem.2004.02.003

45. Tobet SA, Schwarting GA. Minireview: recent progress in gonadotropinreleasing hormone neuronal migration. Endocrinology (2006) 147:1159-65. doi:10.1210/en.2005-1275

46. Cariboni A, Maggi R, Parnavelas JG. From nose to fertility: the long migratory journey of gonadotropin-releasing hormone neurons. Trends Neurosci (2007) 30:638-44. doi:10.1016/j.tins.2007.09.002

47. Silveira LF, Trarbach EB, Latronico AC. Genetics basis for GnRH-dependent pubertal disorders in humans. Mol Cell Endocrinol (2010) 324:30-8. doi:10.1016/j.mce.2010.02.023

48. Franco B, Guioli S, Pragliola A, Incerti B, Bardoni B, Tonlorenzi $\mathrm{R}$, et al. A gene deleted in Kallmann's syndrome shares homology with neural cell adhesion and axonal path-finding molecules. Nature (1991) 353:529-36. doi:10.1038/353529a0

49. Legouis R, Hardelin JP, Levilliers J, Claverie JM, Compain S, Wunderle $\mathrm{V}$, et al. The candidate gene for the $\mathrm{X}$-linked Kallmann syndrome encodes a protein related to adhesion molecules. Cell (1991) 67:423-35. doi:10.1016/00928674(91)90193-3

50. Hardelin JP, Levilliers J, del Castillo I, Cohen-Salmon M, Legouis R, Blanchard S, et al. $\mathrm{X}$ chromosome-linked Kallmann syndrome: stop mutations validate the candidate gene. Proc Natl Acad Sci U S A (1992) 89:8190-4. doi:10.1073/pnas.89.17.8190

51. Dode C, Levilliers J, Dupont JM, De Paepe A, Le Du N, Soussi-Yanicostas N, et al. Loss-of-function mutations in FGFR1 cause autosomal dominant Kallmann syndrome. Nat Genet (2003) 33:463-5. doi:10.1038/ng1122

52. Sato N, Katsumata N, Kagami M, Hasegawa T, Hori N, Kawakita $\mathrm{S}$, et al. Clinical assessment and mutation analysis of Kallmann syndrome 1 (KAL1) and fibroblast growth factor receptor 1 (FGFR1, or KAL2) in five families and 18 sporadic patients. J Clin Endocrinol Metab (2004) 89:1079-88. doi:10.1210/jc.2003-030476

53. Trarbach EB, Abreu AP, Silveira LF, Garmes HM, Baptista
MT, Teles MG, et al. Nonsense mutations in FGF8 gene causing different degrees of human gonadotropin-releasing deficiency. J Clin Endocrinol Metab (2010) 95:3491-6. doi:10.1210/jc.2010-0176

54. Dode C, Teixeira L, Levilliers J, Fouveaut C, Bouchard P, Kottler ML, et al. Kallmann syndrome: mutations in the genes encoding prokineticin-2 and prokineticin receptor-2. PLoS Genet (2006) 2:e175. doi:10.1371/ journal.pgen.0020175

55. Cole LW, Sidis Y, Zhang C, Quinton R, Plummer L, Pignatelli $\mathrm{D}$, et al. Mutations in prokineticin 2 and prokineticin receptor 2 genes in human gonadotrophin-releasing hormone deficiency: molecular genetics and clinical spectrum $J$ Clin Endocrinol Metab (2008) 93:3551-9. doi:10.1210/jc.20072654

56. Kim HG, Kurth I, Lan F, Meliciani I, Wenzel W, Eom SH, et al. Mutations in CHD7, encoding a chromatin-remodeling protein, cause idiopathic hypogonadotropic hypogonadism and Kallmann syndrome. Am J Hum Genet (2008) 83:511-9. doi:10.1016/j.ajhg.2008.09.005

57. Jongmans MC, van Ravenswaaij-Arts CM, Pitteloud N, Ogata T, Sato N, Claahsen-van der Grinten HL, et al. CHD7 mutations in patients initially diagnosed with Kallmann syndrome - the clinical overlap with CHARGE syndrome. Clin Genet (2009) 75:65-71. doi:10.1111/j.13990004.2008.01107.x

58. Bergman JE, Janssen N, Hoefsloot LH, Jongmans MC, Hofstra RM, van RavenswaaijArts CM. CHD7 mutations and CHARGE syndrome: the clinical implications of an expanding phenotype. $J$ Med Genet (2011) 48:334-42. doi:10.1136/jmg.2010.087106

59. Ballabio A, Camerino G. The gene for X-linked Kallmann syndrome: a human neuronal migration defect. Curr Opin Genet Dev (1992) 2:417-21. doi:10.1016/S0959437X(05)80152-2

60. Hardelin JP, Dode C. The complex genetics of Kallmann syndrome: KAL1, FGFR1, FGF8, PROKR2, PROK2, et al. Sex Dev (2008) 2:181-93. doi:10.1159/000152034 
61. Endo $\mathrm{Y}$, Ishiwata-Endo $\mathrm{H}$, Yamada KM. Extracellular matrix protein anosmin promotes neural crest formation and regulates FGF, BMP, and WNT activities. Dev Cell (2012) 23:305-16. doi:10.1016/j.devcel.2012.07.006

62. Hardelin JP, Julliard AK, Moniot B, Soussi-Yanicostas N, Verney C, Schwanzel-Fukuda $\mathrm{M}$, et al. Anosmin-1 is a regionally restricted component of basement membranes and interstitial matrices during organogenesis: implications for the developmental anomalies of $\mathrm{X}$ chromosomelinked Kallmann syndrome. Dev Dyn (1999) 215:26-44. doi:10.1002/(SICI) 10970177(199905)215:1<26::AIDDVDY4>3.0.CO;2-D

63. Soussi-Yanicostas N, de Castro F, Julliard AK, Perfettini I, Chedotal A, Petit C. Anosmin1 , defective in the $\mathrm{X}$-linked form of Kallmann syndrome, promotes axonal branch formation from olfactory bulb output neurons. Cell (2002) 109:217-28. doi:10.1016/S00928674(02)00713-4

64. Hu Y, Guimond SE, Travers P, Cadman S, Hohenester E, Turnbull JE, et al. Novel mechanisms of fibroblast growth factor receptor 1 regulation by extracellular matrix protein anosmin-1. $J$ Biol Chem (2009) 284:29905-20. doi:10.1074/jbc.M109.049155

65. $\mathrm{Hu} \mathrm{Y}$, Poopalasundaram S, Graham A, Bouloux PM. GnRH neuronal migration and olfactory bulb neurite outgrowth are dependent on FGF receptor 1 signaling, specifically via the PI3K p110alpha isoform in chick embryo. Endocrinology (2013) 154:388-99. doi:10.1210/en.2012-1555

66. Gonzalez-Martinez D, Kim SH, Hu Y, Guimond S, Schofield J, Winyard P, et al. Anosmin-1 modulates fibroblast growth factor receptor 1 signaling in human gonadotropinreleasing hormone olfactory neuroblasts through a heparan sulfate-dependent mechanism. J Neurosci (2004) 24:10384-92. doi:10.1523/JNEUROSCI.340004.2004

67. Clemente D, Esteban PF, Del Valle I, Bribian A, Soussi-Yanicostas N, Silva A, et al. Expression pattern of Anosmin-1 during pre- and postnatal rat brain development.
Dev Dyn (2008) 237:2518-28. doi:10.1002/dvdy.21659

68. Ayari B, Landoulsi A, SoussiYanicostas N. Localization and characterization of kal 1.a and kal 1.b in the brain of adult zebrafish (Danio rerio). Brain Res Bull (2012) 88:345-53. doi:10.1016/j.brainresbull.2012. 03.006

69. Chung WCJ, Matthews TA, Tata BK, Tsai PS. Compound deficiencies in multiple fibroblast growth factor signalling components differentially impact the murine gonadotrophin-releasing hormone system. J Neuroendocrinol (2010) 22:944-50.

70. Tsai PS, Brooks LR, Rochester JR, Kavanaugh SI, Chung WCJ. Fibroblast growth factor signaling in the developing neuroendocrine hypothalamus. Front Neuroendocrinol (2011) 32:95-107. doi:10.1016/j.yfrne. 2010.11.002

71. Tata BK, Chung WCJ, Brooks LR, Kavanaugh SI, Tsai PS, Fibroblast growth factor signaling deficiencies impact female reproduction and kisspeptin neurons in mice. Biol Reprod (2012) 86:119. doi:10.1095/ biolreprod.111.095992

72. Brooks LR, Chung WCJ, Tsai PS. Abnormal hypothalamic oxytocin system in fibroblast growth factor 8-deficient mice. Endocrine (2010) 38:174-80. doi:10.1007/s12020-010-9366-9

73. McCabe MJ, Gaston-Massuet C, Tziaferi V, Gregory LC, Alatzoglou KS, Signore M, et al. Novel FGF8 mutations associated with recessive holoprosencephaly, craniofacial defects, and hypothalamo-pituitary dysfunction. J Clin Endocrinol Metab (2011) 96:E1709-18. doi:10.1210/jc.2011-0454

74. Li M, Bullock CM, Knauer DJ, Ehlert FJ, Zhou QY. Identification of two prokineticin cDNAs: recombinant proteins potently contract gastrointestinal smooth muscle. Mol Pharmacol (2001) 59:692-8.

75. Lin DC, Bullock CM, Ehlert FJ, Chen JL, Tian H, Zhou QY. Identification and molecular characterization of two closely related G protein-coupled receptors activated by prokineticins/endocrine gland vascular endothelial growth factor. J Biol Chem (2002) 277:19276-80. doi:10.1074/ jbc.M202139200
76. Masuda Y, Takatsu Y, Terao Y, Kumano S, Ishibashi Y, Suenaga $\mathrm{M}$, et al. Isolation and identification of EG-VEGF/prokineticins as cognate ligands for two orphan G-protein-coupled receptors. Biochem Biophys Res Commun (2002) 293:396402 doi:10.1016/S0006291X(02)00239-5

77. Soga $\mathrm{T}$, Matsumoto $\mathrm{S}$, Oda $\mathrm{T}$, Saito T, Hiyama H, Takasaki J, et al. Molecular cloning and characterization of prokineticin receptors. Biochim Biophys Acta (2002) 1579:173-9. doi:10.1016/S01674781(02)00546-8

78. Ng KL, Li JD, Cheng MY, Leslie FM, Lee AG, Zhou QY. Dependence of olfactory bulb neurogenesis on prokineticin 2 signaling. Science (2005) 308:1923-7. doi:10.1126/science.1112103

79. Matsumoto S, Yamazaki C, Masumoto $\mathrm{KH}$, Nagano $\mathrm{M}$, Naito M, Soga T, et al. Abnormal development of the olfactory bulb and reproductive system in mice lacking prokineticin receptor PKR2. Proc Natl Acad Sci U S A (2006) 103:4140-5. doi:10.1073/pnas.0508881103

80. Pitteloud N, Zhang C, Pignatelli $\mathrm{D}, \mathrm{Li} \mathrm{JD}$, Raivio $\mathrm{T}$, Cole LW, et al. Loss-of-function mutation in the prokineticin 2 gene causes Kallmann syndrome and normosmic idiopathic hypogonadotropic hypogonadism. Proc Natl Acad Sci U S A (2007) 104:17447-52. doi:10.1073/pnas.0707173104

81. Monnier C, Dode C, Fabre L, Teixeira L, Labesse G, Pin $\mathrm{JP}$, et al. PROKR2 missense mutations associated with Kallmann syndrome impair receptor signalling activity. Hum Mol Genet (2009) 18:75-81. doi:10.1093/hmg/ddn318

82. Wierman ME, Kiseljak-Vassil iades K, Tobet S. Gonadotropinreleasing hormone ( $\mathrm{GnRH})$ neuron migration: initiation, maintenance and cessation as critical steps to ensure normal reproductive function. Front $\mathrm{Neu}$ roendocrinol (2011) 32:43-52. doi:10.1016/j.yfrne.2010.07.005

83. Cheng MY, Leslie FM, Zhou QY. Expression of prokineticins and their receptors in the adult mouse brain. J Comp Neurol (2006) 498:796-809. doi:10.1002/cne.21087

84. Prosser HM, Bradley A, Chesham JE, Ebling FJ, Hastings MH, Maywood ES. Prokineticin receptor 2 (Prokr2) is essential for the regulation of circadian behavior by the suprachiasmatic nuclei. Proc Natl Acad Sci U S A (2007) 104:648-53. doi:10.1073/pnas.0606884104

85. Prosser HM, Bradley A, Caldwell MA. Olfactory bulb hypoplasia in Prokr2 null mice stems from defective neuronal progenitor migration and differentiation. Eur J Neurosci (2007) 26:3339-44. doi:10.1111/j.14609568.2007.05958.x

86. Kim HG, Layman LC. The role of CHD7 and the newly identified WDR11 gene in patients with idiopathic hypogonadotropic hypogonadism and Kallmann syndrome. Mol Cell Endocrinol (2011) 346:74-83. doi:10.1016/j.mce.2011.07.013

87. Layman WS, Hurd EA, Martin DM. Reproductive dysfunction and decreased GnRH neurogenesis in a mouse model of CHARGE syndrome. Hum Mol Genet (2011) 20:3138-50. doi:10.1093/hmg/ddr216

88. Gruss P, Walther C. Pax in development. Cell (1992) 69:719-22. doi:10.1016/00928674(92)90281-G

89. Hill RE, Hanson IM. Molecular genetics of the Pax gene family. Curr Opin Cell Biol (1992) 4:967-72. doi:10.1016/09550674(92)90126-W

90. Roberts RC. Small-eyes: a new dominant eye mutation in the mouse. Genet Res (1967) 9:121-2. doi:10.1017/ S0016672300010387

91. Grindley JC, Davidson DR, Hill RE. The role of Pax- 6 in eye and nasal development. Development (1995) 121:1433-42.

92. Hogan BL, Horsburgh G, Cohen J, Hetherington CM, Fisher G, Lyon MF. Small eyes (Sey): a homozygous lethal mutation on chromosome 2 which affects the differentiation of both lens and nasal placodes in the mouse. J Embryol Exp Morphol (1986) 97:95-110.

93. Hill RE, Favor J, Hogan BL, Ton CC, Saunders GF, Hanson IM, et al. Mouse small eye results from mutations in a paired-like homeobox-containing gene. Nature (1991) 354:522-5. doi:10.1038/354522a0

94. Walther C, Gruss P. Pax-6, a murine paired box gene, is expressed in the developing CNS. Development (1991) 113:1435-49. 
95. Schwanzel-Fukuda M, Reinhard GR, Abraham S, Crossin KL, Edelman GM, Pfaff DW. Antibody to neural cell adhesion molecule can disrupt the migration of luteinizing hormone-releasing hormone neurons into the mouse brain. $J$ Comp Neurol (1994) 342:174-85. doi:10.1002/cne.903420203

96. Quinn JC, West JD, Hill RE. Multiple functions for Pax6 in mouse eye and nasal development. Genes Dev (1996) 10:435-46. doi:10.1101/gad.10.4.435

97. Englund C, Fink A, Lau C, Pham D, Daza RA, Bulfone A, et al. Pax6, Tbr2, and Tbr1 are expressed sequentially by radial glia, intermediate progenitor cells, and postmitotic neurons in developing neocortex. $J$ Neurosci (2005) 25:247-51. doi:10.1523/JNEUROSCI.289904.2005

98. Hogan BL, Hirst EM, Horsburgh G, Hetherington CM. Small eye (Sey): a mouse model for the genetic analysis of craniofacial abnormalities. Development (1988) 103(Suppl):115-9.

99. Hanson I, Van Heyningen V. Pax6: more than meets the eye. Trends Genet (1995)
11:268-72. doi:10.1016/S01689525(00)89073-3

100. Dellovade TL, Pfaff DW, Schwanzel-Fukuda M. The gonadotropin-releasing hormone system does not develop in Small-Eye (Sey) mouse phenotype. Brain Res Dev Brain Res (1998) 107:233-40. doi:10.1016/S0165-3806(98) 00007-8

101. Stoykova A, Fritsch R, Walther C, Gruss P. Forebrain patterning defects in small eye mutant mice. Development (1996) 122: 3453-65.

102. Valverde F, Garcia C, LopezMascaraque L, De Carlos JA. Development of the mammillothalamic tract in normal and Pax-6 mutant mice. J Comp Neurol (2000) 419:485-504. doi:10.1002/(SICI)10969861(20000417)419:4<485::AIDCNE6>3.3.CO;2-T

103. Laudet V, Stehelin D, Clevers H. Ancestry and diversity of the HMG box superfamily. Nucleic Acids Res (1993) 21:2493-501. doi:10.1093/nar/21.10.2493

104. van de Wetering $M$, Clevers $H$. Sequence-specific interaction of the HMG box proteins TCF1 and SRY occurs within the minor groove of a Watson-Crick double helix. EMBO J (1992) 11: 3039-44.

105. Connor F, Cary PD, Read CM, Preston NS, Driscoll PC, Denny $\mathrm{P}$, et al. DNA binding and bending properties of the post-meiotically expressed Sryrelated protein Sox-5. Nucleic Acids Res (1994) 22:3339-46. doi:10.1093/nar/22.16.3339

106. Harley VR, Lovell-Badge R, Goodfellow PN. Definition of a consensus DNA binding site for SRY. Nucleic Acids Res (1994) 22:1500-1. doi:10.1093/nar/22.8.1500

107. Collignon J, Sockanathan S, Hacker A, Cohen-Tannoudji M, Norris D, Rastan S, et al. A comparison of the properties of Sox-3 with Sry and two related genes, Sox-1 and Sox-2. Development (1996) 122:509-20.

108. Uwanogho D, Rex M, Cartwright EJ, Pearl G, Healy C, Scotting PJ, et al. Embryonic expression of the chicken Sox2, Sox3 and Sox11 genes suggests an interactive role in neuronal development. Mech Dev (1995) 49:23-36. doi:10.1016/09254773(94)00299-3

109. Kim HD, Choe HK, Chung S, Kim M, Seong JY, Son GH, et al. Class-C SOX transcription factors control GnRH gene expression via the intronic transcriptional enhancer. $\mathrm{Mol}$ Endocrinol (2011) 25:1184-96. doi:10.1210/me.2010-0332

Conflict of Interest Statement: The authors declare that the research was conducted in the absence of any commercial or financial relationships that could be construed as a potential conflict of interest.

Received: 26 April 2013; accepted: 02 July 2013; published online: 16 July 2013.

Citation: Stevenson EL, Corella KM and Chung WCJ (2013) Ontogenesis of gonadotropin-releasing hormone neurons: a model for hypothalamic neuroendocrine cell development. Front. Endocrinol. 4:89. doi: 10.3389/fendo.2013.00089

This article was submitted to Frontiers in Experimental Endocrinology, a specialty of Frontiers in Endocrinology. Copyright $(\odot) 2013$ Stevenson, Corella and Chung. This is an open-access article distributed under the terms of the Creative Commons Attribution License, which permits use, distribution and reproduction in other forums, provided the original authors and source are credited and subject to any copyright notices concerning any third-party graphics etc. 